\title{
Constitutional Sanctions
}

\section{in the Context of Punishability}

\author{
Nina M. Kolosova and Iulia A. Livadnaia* \\ Institute of Legislation and Comparative Law \\ under the Government of the Russian Federation \\ 34, B. Cheremushkinskaya Str, Moscow, 117218, Russia
}

Received 25.02.2019, received in revised form 11.03.2019, accepted 18.03.2019

This article is devoted to the study of the issue of constitutional sanctions through the lens of such an essential feature of offense as punishability, which still has not been analysed thoroughly in the legal literature. On the basis of a comparative legal analysis of the constitutional norms of different countries of the world, the authors have developed certain approaches to describing the characteristic of punishability of both crimes and offenses in general. With regard to the constitutional and legal delict as a definite type of offense, the problem of punishability has been proposed to be considered in view of the legal nature and types of constitutional sanctions. The authors made the conclusion that the characteristic of punishability for a constitutional and legal delict should be seen as one of the criteria for singling out the constitutional sanction itself. The study of the legal nature of constitutional and legal delicts prepared the ground for the classification of constitutional sanctions according to the nature and extent of measures of state coercion applied to a person who has committed a constitutional and legal delict.

Keywords: constitution, constitutional and legal delict, punishability, sanction, preventive measures, constitutional liability.

Research area: law.

Citation: Kolosova, N.M., Livadnaia I.A. (2019). Constitutional Sanctions in the Context of Punishability. J. Sib. Fed. Univ. Humanit. soc. sci., 12(3), 492-503. DOI: 10.17516/19971370-0379.

\section{Introduction}

The relevance of this study is determined by the increasing weight and importance of the constitutional responsibility of state authorities and their officials, which is logical for democracy. In this regard, it seems necessary to look into the issue of constitutional

(C) Siberian Federal University. All rights reserved

* Corresponding author E-mail address: const@izak.ru

This work is licensed under a Creative Commons Attribution-NonCommercial 4.0 International License (CC BY-NC 4.0). 
sanctions through a lens of such an essential feature of the offense as punishability, which, in our opinion, has not been covered enough in the specialised literature. In addition, in this article we will try to highlight the features of constitutional sanctions versus criminal ones, in which the punishability of a crime is obvious.

Based on the general theory of the offense, one can assume that a constitutional and legal delict, as well as other types of offenses, in addition to threats of public danger (public harm), wrongfulness, guilt, is an intrinsic sign of punishability, which implies functioning of negative consequences in the form of the application of constitutional sanctions in case the norms of law are violated [Livadnaia, 2016].

The constitutions of different states differ in what to consider a characteristic of punishability. In a number of constitutions, only crimes are punishable (in such countries as Greece, Germany, Spain, Poland, Pakistan, United Arab Emirates, Venezuela and others). The constitutional and legal norms of other states reflect a more general approach of the legislator to punishability as a characteristic of an offense in general. Thus, according to Part 2 of Article 54 of the Constitution of the Russian Federation, "no one may be held liable for an act that was not recognized as an offense at the time of its commission". A similar approach is found, for example, in Article 16 of the Constitution of the Netherlands, according to which "no offence shall be punishable unless it was an offence under the law at the time it was committed" [Okun'kov, 2001, p. 615]. Article 25 of the Italian Constitution states that: “...No punishment may be inflicted except by virtue of a law in force at the time the offence was committed" [Ibid, p. 108]. A similar rule is fixed in paragraph "a" of Part 1 of Article 12 of the Constitution of The Islamic Republic of Pakistan, in accordance with which "no law shall authorise the punishment of a person for an act or omission that was not punishable by law at the time of the act or omission..." [Khabrieva, 2010, p. 620].

We believe that the issue of the punishability of constitutional and legal delicts should be studied taking into account the constitutional sanctions, which would allow us to build their system.

According to the Constitution of the Russian Federation, the sanctions are:

- impeachment of the President of the Russian Federation by the Council of the Federation (Article 93);

- dismissal of the Procurator-General of the Russian Federation by the Council of the Federation upon the proposal of the President of the Russian Federation (Part 2 of Article 129) and other cases of dismissal from office, enshrined in the Constitution of the Russian Federation; 
- suspension of acts of the Bodies of executive power of the subjects of the Russian Federation by the President of the Russian until the issue is solved by a corresponding court (Part 2 of Article 85);

- cancellation by the President of the Russian Federation of decisions and orders of the Government in case they are inconsistent with the Constitution of the Russian Federation, federal laws and decrees of the President of the Russian Federation (Part 3 of Article 115);

- expression of no-confidence to the Government of the Russian Federation by the State Duma (Part 3 of Article 117);

- raising a question before the State Duma by the Chairman of the Government of the Russian Federation about confidence to the Government of the Russian Federation (Part 4 of Article 117);

- decision of the President of the Russian Federation on the resignation of the Government of the Russian Federation (Article 117);

- dissolution of the State Duma by the President of the Russian Federation (Article 109);

- recognition by the Constitutional Court of the Russian Federation of laws, regulations or their separate provisions as unconstitutional (Article 125);

- introduction of a state of emergency by the President of the Russian Federation in the territory of the Russian Federation or in its certain parts (Article 88);

- deprivation of immunity of deputies and members of the Council of Federation by the corresponding chamber of the Federal Assembly upon the proposal of the Procurator-General of the Russian Federation (Part 2 of Article 98).

Some of the above constitutional formulations do not allow us to state unambiguously that certain measures are sanctions. For example, the dissolution of the State Duma should be seen as a constitutional sanction only if there is a constitutional and legal delict in its actions, which is not adequately set in the Constitution of the Russian Federation. It seems that a characteristic of the punishability of a constitutional and legal delict should be regarded as one of the criteria for regarding it as a constitutional sanction. Yet, the problem of recognition or non-recognition of preventive sanctions remains disputable. Thus, all kinds of preventive measures taken before stating the fact of the presence of a constitutional and legal delict are suggested to be considered as measures of preventive influence, rather than constitutional sanctions. An example of such a measure is a warning about the unacceptability of violation of the law as an act of prosecutorial response, as written in Art. 25.1 of the Federal Law of January 17, 1992 
No. 2202-1 "On the Prosecutor's Office of the Russian Federation": "For the purposes of preventing law offences and if there exists information on the prepared illegal actions, the public prosecutor or his deputy shall forward in writing to the officials, and if there exists information on the prepared illegal actions containing the signs of extremist activity - to the leaders of public (religious) associations and to the other persons, a warning on the inadmissibility of the violation of law" [Collected Legislation]. We accept as true that preventive measures can be attributed to sanctions only if they contain a constituent of the punishability for the corresponding constitutional and legal delict.

In the literature devoted to legal issues there are a number of definitions of the concept of constitutional (constitutional-legal) sanctions. So, according to V.O. Luchin, sanctions are measures of state coercion ("legal deprivations, burdens, legal damage") set by the Constitution [Luchin, 1992]. V.A. Vinogradov holds opinion that "a constitutional legal sanction is a prescribed by the norms of constitutional law either state or (equivalent) public act of influence in the sphere of constitutional legal relations, which is applied when actual behaviour does not conform to the proper behaviour established by the disposition of the constitutional legal norm, and which contains its final estimation" [Vinogradov, 2000].

The specialised literature also gives the following definition for the constitutional sanctions: "the possibility of adverse consequences through legislative coercion against the subject of law in cases of their non-fulfillment of constitutional obligations or in the case of abuse of their rights" [Kolosova, 2000, p. 110].

The above mentioned definitions generally clarify the legal nature of this concept, though the situation is complicated by the fact that the structure of the norms of the Constitution of the Russian Federation, as well as of the Constitution of a number of foreign countries, does not always imply the existence of sanctions. Meanwhile, we agree completely with the statement of S.N. Bratus' that "a norm without a sanction ceases to be a measure, a scale of behaviour, since the violation of this measure, going beyond the specified framework, will not entail proper reaction, state condemnation and state coercion, providing for the regulation of disturbed social relations in the form of feedback" [Bratus', 1976, p. 68].

It appears that "the mere fact of the belonging of a specific measure of responsibility to the Basic Law does not automatically turn it into a constitutional sanction" [Kolosova, 2000, p. 110]. Such sanctions can be found in the constitutional and legal norms in a number of states. In the Constitution of the Russian Federation the most striking 
example is paragraph 2 of Article 20, according to which "capital punishment until its complete elimination may be envisaged by a federal law as an exclusive penalty for especially grave crimes against life, and the accused shall be granted the right to have their case examined by jury trial". Moreover, while Russian constitutional and legal norms contain only several cases of such sanctions, an analysis of the constitutions of other countries of the world shows that the text of the main law can not only regulate the procedure for imposing certain types of punishments (capital punishment, prolonged imprisonment, confiscation of property), but also dictate their system (for instance, in Article XLVI of the Constitution of Brazil) [Khabrieva, 2006, p. 128].

The question of the punishability of constitutional and legal delicts in terms of sanctions still remains controversial. The main direction of the related research is connected, first of all, with the study of the relationship between constitutional responsibility and sanctions. Currently, there are three main approaches to this problem's solution:

- notions of responsibility and sanctions are equivalent (O.E. Leist) ${ }^{1}$ [Leist, 1981, p. 97];

- the concept of constitutional responsibility is broader than the concept of constitutional sanctions, since it presupposes the existence of principles of responsibility and conditions of exemption from liability, mitigating and aggravating circumstances (V.O. Luchin, V.A. Vinogradov, etc.) [Luchin, 1992, pp. 36-37, Vinogradov, 2000, p. 57];

- the concept of constitutional sanctions is broader than the concept of constitutional responsibility, since it presupposes the existence of preventive sanctions (assessment of certain state authorities as unsatisfactory, written warning of registering authorities about non-compliance of public associations with their statutory goals, etc.).

Having analysed these approaches, we suppose that the most productive is to understand constitutional responsibility as the implementation of a sanction, since otherwise the characteristic of the punishability of constitutional and legal delict is offset. At the same time, constitutional responsibility can be considered as a broader concept than sanctions, if we take as the basis the theory of constitutional responsibility, which cannot be reduced only to the study of constitutional sanctions. The judgement on the equivalence of the concepts under consideration does not take into account a number of essential principles and conditions that ultimately

According to O.E. Leist, there is a defining direct connection between liability and a sanction: without sanctioning there is no liability of the subject. 
affect the nature and amount of sanctions or may lead to exemption from liability. More to the point, a broader understanding of constitutional sanctions at the expense of the notion of constitutional responsibility is not perceived as entirely justified, since it violates the general theoretical postulate that the basis of legal liability is corpus delicti [Mal'ko, 2014, p. 284].

The crucial role of the Constitutional Court of the Russian Federation is obvious as its legal positions develop the theory of constitutional sanctions. In particular, when discussing the possibility of fixing constitutional sanctions in federal laws, one of the fundamental arguments for decision to be made by the Constitutional Court of the Russian Federation was the provision of Article 15 of the Constitution of the Russian Federation.

In paragraph 2 of the Resolution of the Constitutional Court of the Russian Federation dated 04.04.2002 it was noted that the need for adequate measures of federal influence in relation to the legislative body of state power of a subject of the Russian Federation or the highest official of a subject of the Russian Federation is enshrined in the Federal Law "On the general principles of organizing legislative (representative) state power bodies of the subjects of the Russian Federation" and is conditioned by fixing in Article 15 of the Constitution of the Russian Federation of these bodies' constitutional obligation to comply with the Constitution of the Russian Federation and federal laws.

The direct effect of the Constitution of the Russian Federation implies both the application of constitutional norms directly and together with the norms of legislation. For example, the Federal Constitutional Law "On the Government of the Russian Federation" enlists the measures of constitutional responsibility applied by the Government of the Russian Federation to other legal entities. Thus, according to Article 12 of the Federal Constitutional Law "On the Government of the Russian Federation", the Government of the Russian Federation has the right to cancel acts of federal executive bodies or suspend the actions of these acts. According to Article 44 of the Federal Constitutional Law "On the Government of the Russian Federation", the Government of the Russian Federation makes a proposal to the President of the Russian Federation on the suspension of acts of bodies of executive power in any subject of the Russian Federation if these acts contradict the Constitution of the Russian Federation, federal constitutional laws, federal laws, international obligations of the Russian Federation or violate human and civil rights and freedoms. The application of these norms is carried out simultaneously with the corresponding constitutional norms. 
It should also be mentioned that constitutional sanctions can be fixed in the legislation more thoroughly than in the text of the Constitution of the Russian Federation. For example, according to Part 1 of Article 6 of the Constitution of the Russian Federation the acquisition and termination of citizenship of the Russian Federation is carried out in accordance with federal law. In addition, the Constitution of the Russian Federation reads as follows: "A citizen of the Russian Federation may not be deprived of his or her citizenship or of the right to change it" (Part 3 of Article 6 of the Constitution of the Russian Federation). In the RSFSR Law "On Citizenship of the RSFSR" and in the current federal law "On the Citizenship of the Russian Federation" there are norms providing for the application of measures of constitutional liability [Supreme Soviet, 1993]. The point is that the decision on the citizenship of the Russian Federation is cancelled in relation to the person who acquired the citizenship of the Russian Federation on the basis of knowingly false information and false documents (Article 22). At the same time, the direct effect of the constitutional norms is felt in the process of applying these specific norms of sectoral legislation.

In the modern legal literature, there are a lot of original lists (by D.T. Shon, T.D. Zrazhevskaia, V.O. Luchin and others) and classifications of constitutional sanctions based on various criteria.

S.A. Avak'ian, defining the legal nature of sanctions as measures of negative constitutional and legal responsibility, grouped them as follows. He had previously indicated that there is a certain degree of conventionality in such a classification, which takes into account a. the circle of people to whom the relevant measures are applied and b. focus on the protection of certain legal relations.

1. Measures taken to individuals and legal entities to ensure the interests of the state and the people (cancellation of the previously adopted decision on citizenship, liquidation of a public association and prohibition of its activities by a court decision, etc.);

2. Measures taken to ensure federal and other "vertical" legal relations (taking measures to repeal a legal act; early termination of powers of a state authority or the highest official of a subject of the Russian Federation, etc.);

3. Measures taken in connection with the realization of the electoral rights of citizens and the organization of the electoral process in the Russian Federation (deprivation or suspension of electoral rights of a citizen, admitting elections invalid, etc.);

4. Measures taken in connection with the activities of bodies of state authorities and local self-government, as well as with the activities of deputies and officials (the 
dissolution of the legislative body of power, discharge from office of an elected official, etc.) [Avak'ian, 2014].

It seems likely that the main reason for the classification of sanctions is negative consequences and the nature or method of legislative coercion against violators of constitutional law. Accordingly, there are four types of sanctions: restorative justice (admitting that the federal law is unconstitutional, etc.); precautionary (a written warning of the judicial authorities on the termination of the activities of a public association, etc.); penalties aimed at punishing the offender (early elections, impeachment of the President, deprivation of citizenship, etc.), i.e. punitive sanctions; sanctions for restraints (the introduction of a state of emergency, the suspension of the acts of the bodies of executive power of the subjects of the Russian Federation, the veto of the President of the Russian Federation) [Kolosova, 2000, pp. 113-114].

V.A. Vinogradov divides constitutional and legal sanctions into basic sanctions, which are used exclusively as main, independent sanctions and additional sanctions that can be used in addition to basic ones [Vinogradov, 2000, p. 76].

The classification of sanctions developed by this researcher is based on their essential typical features; various constitutional and legal sanctions are grouped into types, revealing the basic laws of their normative definition and application.

1. Deprivation of a general or special constitutional legal status, early termination (deprivation) of powers (dissolution; disbandment; prohibition of activities; discharge from office, deprivation of a mandate; revocation; deprivation of citizenship; deprivation of state awards and honorary titles; cancellation of registration, exclusion from state registry);

2. Restriction, deprivation (withdrawal) of a subjective constitutional right (for example, restriction on passive and active electoral right);

3. Refusal (recognition (non-recognition) of mandates, approval (non-approval) of acts (reports), signing an act (or its part) in case of its unconstitutionality (illegality), etc.));

4. Granting another member of constitutional and legal relationship an additional constitutional right (authority), the imposition of a constitutional duty (for example, compelling the prime minister to submit a letter of resignation of the cabinet of ministers in connection with the expression of no-confidence to the parliament);

5. Transfer of constitutional powers (for example, the transfer of the right to sign laws from the head of state to the chairman of parliament if the former evades signing them in the prescribed manner); 
6. Evaluative (expenditial) sanctions (expression of no-confidence (attributing activity as unsatisfactory), revocation; recognition of something as unconstitutional (anticonstitutional); expression of objection; submission on suppression of improper behaviour and its prevention; admitting actions as being unconstitutional (illegal));

7. Cancellation (invalidation) of a legally significant result (for example, announcement that collected voter signatures in support of a candidate, federal list of candidates are invalid);

8. Cancellation (suspension), attestation of acts as being unconstitutional;

9. Coercion to fulfill constitutional duties (federal intervention (coercion, intervention); suspension of one's own administration, imposition of presidential rule; expulsion, removal, deportation);

10. Constitutional and legal sanctions of a procedural nature (for example, a warning, a reprimand, temporary suspension from participation in the work of parliament);

11. Constitutional and legal sanctions of financial (property) nature [Ibid, pp. 78-99].

The extent of detalization of this issue dispels the thesis that legal sanctions are universal in nature, and the effect of constitutional norms can be ensured by sanctions of other law branches [Avak'ian, 2014, pp. 101-103]. Analysis of modern approaches makes it possible to outline the following peculiarities of constitutional sanctions:

- unlike sanctions in criminal law, the list of constitutional sanctions is not exhaustive;

- constitutional sanctions for the most part are original and cannot act as sanctions for other types of legal liability. The exceptions are the sanctions concerning compensation of material damage, which can act as sanctions of not only civil, but also of constitutional liability [Kolosova, 2000, p. 113], and also deprivation of state awards and honorary titles [Vinogradov, 2000, p. 83], which by its nature is a criminal punishment (Article 48 of the Criminal Code of Russia).

The above analysis of the different classifications of constitutional sanctions gives a chance to acknowledge the importance of each of them. Furthermore, depending on the objectives of the study, other typologies of constitutional sanctions are viable.

As a result, we can admit that, for example, such grounds as the negative consequences and the nature or method of legislative coercion against violators of constitutional legislation are significant for classification of sanctions. Taking into account the legal nature of constitutional and legal delicts as offenses based on crimes, wrong-doing and even immoral behaviour, we believe that nowadays there is a foundation for a new classification of constitutional sanctions, related to the nature 
and scope of measures of state coercion applied to a person who has committed a constitutional and legal delict. The main actors here are the following:

1. The very constitutional sanctions, which are self-sufficient and ensure the full restoration of social justice;

2. Comprehensive sanctions requiring the combination of constitutional sanctions and sanctions of other law branches applied simultaneously. In this case, one can discern the constitutional, legal and sectoral constituents of the sanction.

In turn, comprehensive sanctions can also be divided into two groups:

- according to the procedure of application:

a) sanctions with the preceding application of the constitutional and legal constituent (for example, in case of deprivation of the special status (immunity) of the deputy, and then bringing this person to criminal or administrative responsibility);

b) sanctions followed by the application of the constitutional and legal constituent (for example, deprivation (limitation) of the right to vote, civil rights or deprivation of citizenship if a person is sentenced to imprisonment);

c) sanctions with the simultaneous use of the constitutional and legal constituent and the sectoral constituent (for example, in case a deputy is detained at the place of the commission of a particularly serious crime).

- according to the branch of law, the sanctions of the norms of which are applied together with the constitutional sanction:

a) comprehensive sanctions with the criminal and legal constituent (discharge from office of the head of state in case of his/her committing high treason with the subsequent imposition of criminal punishment based on the sanction of the corresponding provision of criminal law);

b) comprehensive sanctions with the administrative and legal constituent (prohibition of a public association in case of propaganda and public demonstration of Nazi paraphernalia or symbols with the imposition of penalties during prosecution);

c) comprehensive sanctions with the civil and legal constituent (on the example of a number of states in Asia and the Caribbean, whose constitutional norms prescribe the loss of a deputy's or senator's mandate if a person is declared an insolvent debtor when he/she has not met debt obligations);

d) comprehensive sanctions with the disciplinary constituent (on the example of Brazil, where, in accordance with constitutional norms, a deputy or a senator loses the mandate if he/she does not attend at least every third regular meeting during each legislative session of the chamber which he/she belongs to). 
To sum up, the obligatory presence of a characteristic of punishability, that is the application of prescribed by the law measures of state influence to the person who committed the corresponding offense, is typical of a constitutional and legal delict on a par with other types of offenses. However, unlike sanctions in criminal law, the list of constitutional sanctions is not complete. Besides, the legal nature and procedure for their application in case of constitutional and legal delicts, which are based on corpus delicti, demands the combination of constitutional sanctions and criminal penalties in a certain sequence, which depends on the nature of the offense and the legal status of the delinquent.

\section{References}

Avak'ian, S.A. (2014). Konstitutsionnoe pravo Rossii. Uchebnyi kurs: ucheb. posobie: $v 2 t$. [Constitutional law of Russia. Learning course: a textbook in 2 Vols], 1. Moscow, "Norma", "INFRA-M",108-124.

Bratus', S.N. (1976). Iuridicheskaia otvetstvennost' i zakonnost'. Ocherk teorii [Legal liability and legality. Overview of theory]. Moscow, "Iuridicheskaia literatura".

Khabrieva, T.Ia. (ed.). (2010). Konstitutsii gosudarstv Azii: v 3 t. [Constitutions of Asian States: in 3 Vols.], 2. Moscow, Institute of Legislation and Comparative Law under the Government of the Russian Federation.

Khabrieva, T.Ia. (ed.). (2006). Konstitutsii gosudarstv Ameriki: v 3 t. [Constitutions of American States: in 3 Vols.], 3. Moscow, Institute of Legislation and Comparative Law under the Government of the Russian Federation.

Kolosova, N.M. (2000). Konstitutsionnaia otvetstvennost'v Rossiiskoi Federatsii: Otvetstvennost' organov gosudarstvennoi vlasti i inykh sub'ektov prava za narushenie konstitutsionnogo zakonodatel'stva Rossiiskoi Federatsii [Constitutional liability in the Russian Federation: Responsibility of state authorities and other subjects of law for violation of the constitutional legislation of the Russian Federation]. Moscow, "Gorodets".

Leist O.E. (1981). Sanktsii i otvetstvennost' po sovetskomu pravu. Teoreticheskie problemy [Sanctions and liability according to Soviet law. Theoretical issues]. Moscow, Publishing House of Moscow State University.

Livadnaia, Iu.A. (2016). Nekotorye aspekty sootnosheniia poniatii konstitutsionnopravovogo delikta $\mathrm{i}$ prestupleniia [Some aspects of the relationship between the concepts of a constitutional and legal delict and a crime], In Zhurnal rossiskogo prava [Journal of Russian law], 8, 117-124. 
Luchin, V.O. (1992). Otvetstvennost' v mekhanizme realizatsii Konstitutsii [Liability in the mechanism for implementing the Constitution], In Pravo i zhizn' [Law and life], 1.

Mal'ko, A.V. (ed.). (2014). Teoriia gosudarstva i prava [Theory of state and law]. Moscow, "KNORUS".

Okun'kov, L.A. (ed.). (2001). Konstitutsii gosudarstv Evropy: v 3 t. [Constitutions of European States: in 3 Vols.], 2. Moscow, Publishing House "NORMA".

Sobranie zakonodatel'stva Rossiiskoi Federatsii [Collected Legislation of the Russian Federation], 30, Article 3029. 2002

Supreme Soviet of the Russian Federation (1992), 6, Article 243; (1993), 29, Article 1112.

Vinogradov, V.A. (2000). Konstitutsionnaia otvetstvennost': teoriia i pravovoe regulirovanie [Constitutional liability: theory and legal regulation]. Moscow.

\section{Конституционные санкции \\ в контексте признака наказуемости}

Н.М. Колосова, Ю.А. Ливадная Институт законодательства и сравнительного правоведения при Правительстве Российской Федерации 117218, Москва, Б. Черемушкинская ул., д.34

Настоящая статья посвящена изучению вопроса о конституционных санкциях в аспекте такого существенного признака правонарушения, как наказуемость, которому до настоящего времени уделялось недостаточно внимания в юридчческой литературе. На основании сравнительно-правового анализа конституционных норм стран мира авторами выявлены подходы к определению признака наказуемости как преступлений, так и правонарушений в цеелом. В отношении конституционно-правового деликта как самостоятельного вида правонарушения вопрос наказуемости предложено рассматривать с учетом правовой природы и видов конституционных санкиий. Сделан вывод о том, что признак наказуемости конституциионно-правового деликта следует рассматривать как один из критериев выделения именно конституционной санкиии. На основании изучения правовой природы конституционно-правовых деликтов предложена авторская классификащии конституциионных санкиий, исходя из характера и объема мер государственного принуждения, применяемого к лицу, совериивиему конституциионно-правовой деликт.

Ключевые слова: конституция, конституционно-правовой деликт, наказуемость, санкциия, предупредительные меры, конституциионная ответственность.

Научная специальность: 12.00.00 - юридические науки. 